\title{
Tingkat Tutur dalam Bahasa Sasak dan Bahasa Jawa
}

\author{
Sudirman Wilian
}

\begin{abstract}
AвSTRACт This paper discusses about speech levels in Sasak, the language of the indigenious people of the island of Lombok, examining the style, meaning and some historical background of the speech levels. Based on the data, it shows that Sasak, like Javanese and Balinese, also contains low, mid, high and few honorific vocabularies which are assumed to have been borrowed from Javanese (Steven, 1975; Nothofer, 1975). However, the use of the high and honorific variations are scarecly heard in the everyday common Sasaks conversation. In most occurrences, the high speech level is pronounced only among the so called menak Sasaks and its surrounding. Therefore, it rejects the idea that Sasak speech levels is as elaborate and complex as Javanese due to the fact that Sasak has only a few high and honorific vocabularies known by the Sasak aristocracy.
\end{abstract}

KeYwords Bahasa Sasak, Bahasa Jawa, tingkat tutur, bentuk kesantunan, tindak tutur.

Dalam setiap masyarakat penutur suatu bahasa pastilah dikenal bentukbentuk kesantunan untuk menyatakan hormat dalam berkomunikasi atau bertindak tutur antarsesama. Setiap bahasa memiliki cara-cara tertentu untuk menunjukkan sikap hubungan antara orang yang berbicara dan lawan bicaranya yang dapat menunjukkan tingkat kesantunan di antara kedua belah pihak. Salah satu representasi kesantunan dalam bertindak tutur itu adalah pemakaian bentuk-bentuk ungkapan atau keberadaan tingkat tutur yang membedakan apakah suatu tuturan (ucapan) seseorang itu santun atau tidak. Memang tidak semua bahasa mengenal adanya tingkat tutur dalam repertoar masyarakat pendukungnya. Meskipun demikian, wujud kesantunan juga dapat dinyatakan dengan apa yang dikenal dalam komponen kebahasaan sebagai paralanguage atau suprasegmental features. Lazimnya, tingkat tutur kebanyakan bahasa yang telah diketahui dinyatakan dengan pemakaian pronomina yang berbeda-beda untuk menunjukkan perbedaan rasa hormat itu. Secara garis besar, bentuk tingkat tutur dalam suatu bahasa dapat dibedakan menjadi dua, yakni bentuk hormat dan bentuk biasa, yang masing-masing pemakaiannya bergantung pada relasi antara si penutur dengan petutur atau mitra tutur. Akan tetapi, tidak semua bahasa mempunyai bentuk tingkat tutur yang sama. Dalam bahasa Jawa, misalnya, dikenal tingkat tutur halus yang berfungsi membawakan rasa kesopanan yang tinggi, kemudian tingkat tutur menengah untuk menyatakan rasa kesopanan yang sedang, dan tingkat tutur 
biasa yang berfungsi menunjukkan rasa kesopanan rendah (Soepomo 1979). Bentuk yang pertama disebut tingkat tutur krama, yang kedua tingkat tutur madya, dan yang ketiga dinamakan tingkat tutur ngoko.

Tingkat tutur itu mengacu kepada suatu sistem kode penyampaian rasa kesopanan oleh penutur kepada petutur yang didalamnya terdapat unsur kosakata tertentu, aturan sintaksis tertentu, aturan morfologis dan fonologis tertentu pula (Soepomo 1979). Tulisan ini dimaksudkan untuk menanggapi dan memperjelas tulisan mengenai analisis historis tingkat tutur bahasa Sasak yang dibahas oleh Nothofer dalam tulisan berjudul "A Preliminary Analysis of the History of Sasak Language Levels", dalam SASAK: Working Papers in Sasak, Vol. 2," (Austin ed. 2000), yang diterbitkan oleh Departement of Linguistics and Applied Linguistics, The University of Melbourne. Pada intinya tulisan itu mengemukakan bahwa sistem 'tingkat tutur' bahasa Sasak sama terperinci dan sama rumit dengan sistem tingkat tutur bahasa Jawa. Hal itu didasarkannya pada analisis banyaknya kosakata halus bahasa Sasak yang kemungkinan berasal dari kosakata bahasa Jawa atau bahasa Bali. Pembahasan kemudian akan ditinjau dari sudut teori dan kajian tingkat tutur yang sudah dilakukan terhadap beberapa bahasa. Teori dan hasil kajian itu kemudian dipakai untuk menganalisis data yang sudah ada di dalam tulisan Nothofer dan beberapa data lain dari saya sebagai penutur asli (native speaker) nonmenak atau bukan bangsawan, yang repertoar kosakata halusnya berbeda dari golongan menak (bangsawan). Di samping itu, data juga diambil dari buku bahan pelajaran bahasa Sasak untuk SMP kelas satu dan kelas dua Reramputan Pelajaran Basa Sasak yang disusun oleh Lalu Muhammad Azhar. Data tersebut kemudian dibandingkankan dengan data dalam bahasa Jawa dari berbagai sumber, di samping dari pengetahuan saya yang sudah lama menggunakan bahasa Jawa.

\section{TingKat Tutur}

Beberapa literatur menunjukkan bahwa penelitian dan analisis mengenai sistem tingkat tutur dalam beberapa bahasa sudah banyak dilakukan oleh para peneliti bahasa, khususnya para sosiolinguis. Soepomo (1968 dan 1979), misalnya, telah meneliti dan menulis sistem tingkat tutur dalam bahasa Jawa yang diterbitkan oleh Depdikbud pada tahun 1979. Soepomo membagi bentuk tingkat tutur dalam bahasa Jawa, seperti sudah disinggung di atas, menjadi krama, madya, dan ngoko. Tiap-tiap bentuk tingkat tutur dibagi lagi menjadi tiga, seperti tampak dalam tabel di bawah ini. 
TABEL 1 TINGKAT TUTUR DALAM BAHASA JAWA

\begin{tabular}{|c|c|}
\hline Krama & $\begin{array}{c}\text { Muda Krama } \\
\text { Kramantara } \\
\text { Wreda Krama }\end{array}$ \\
\hline Madya & $\begin{array}{c}\text { Madya Krama } \\
\text { Madyantara } \\
\text { Ngoko }\end{array}$ \\
\hline Ngoko & Basa Antya \\
& Antya Basa \\
& Ngoko Lugu \\
\hline
\end{tabular}

(Sumber: Rahardi, 2001:58)

Menurut Soepomo, tingkat tutur bahasa Jawa itu sendiri sebenarnya hanya dibagi dua, yaitu tingkat ngoko dan basa. Namun, tingkat ngoko ini dapat berbentuk macam-macam: ada bentuk yang dianggap halus dan ada pula yang dianggap biasa. Semakin banyak kata krama, krama inggil, atau krama andap dalam suatu ujaran, semakin haluslah tingkat ngoko itu.

Sebelumnya, Martin (dalam Hymes 1964: 407-413) membandingkan tingkat tutur bahasa Korea dengan bahasa Jepang. Dia mengemukakan bahwa kalimat dalam bahasa Korea dan Jepang dianggap sudah lengkap hanya dengan sebuah predikat - sering hanya dengan sebuah bentuk kata kerja tanpa subjek. Namun, sebelum mengucapkan kata kerja tersebut, orang Korea dan Jepang terlebih dahulu harus memilih tingkat tuturnya, yang ditentukan berdasarkan dua poros perbedaan (axes of distinction): poros pengacuan (axis of reference) dan poros penyapaan (axis of address) (lihat Bagan 1 dalam Lampiran). Pada poros penyapaan dalam bahasa Jepang, tingkat tutur dibagi ke dalam bentuk biasa (plain), sopan (polite), dan hormat (deferential), sedangkan dalam bahasa Korea, pemilihan poros penyapaan terlebih dahulu harus diketahui apakah seseorang masuk dalam kelompok (ingroup) atau di luar kelompok (outgroup). Bila lawan bicara masuk pada kelompok pertama, tingkat tutur harus dipilih: biasa (plain), akrab/intim (intimate), atau sekadar kenal (familiar), dan apabila masuk pada kelompok kedua harus dipilih antara bentuk: sopan (polite), otoritatif (authoritative) atau hormat (deferential). Tiap-tiap bentuk ditandai oleh sufiks tertentu pada kata kerjanya. Singkatnya, pemilihan bentuk biasa, sopan, dan hormat, baik dalam bahasa Jepang maupun Korea, bergantung pada sikap penutur terhadap lawan bicaranya atau orang yang dibicarakan, sedangkan pilihan bentuk tutur merendah (humble), netral (neutral) atau meninggi (exalted) bergantung terutama pada sikap pembicara pada subjek pembicaraan. Martin menyimpulkan bahwa sistem tingkat tutur dalam dua bahasa serumpun ini begitu kompleks yang ditentukan oleh perbedaan usia, jenis kelamin, kedudukan sosial, keanggotaan dalam kelompok. Sejalan dengan hal ini, Holmes (1992: 271) juga berpendapat bahwa pilihan atas bentuk tutur yang sesuai untuk digunakan juga tidak hanya ditentukan oleh 
ucapan, tetapi oleh bentukan kata dan sintaksisnya.

Dalam literatur lain ditemukan pula bahwa tingkat tutur dalam banyak bahasa ditentukan pula oleh pemakaian bentuk sapaan (address system) bahasa bersangkutan. Misalnya dalam bahasa Inggris, penyebutan nama kedua atau nama keluarga yang didahului sebutan gelar tuan atau nyonya (title with last name) atau nama pertama/panggilan akrab (nick name) dapat menunjukkan tingkat tutur sekaligus kesantunan pembicara terhadap lawan bicaranya (Brown dan Ford dalam Hymes 1964). Demikian pula dalam bahasa Parsi di Iran, usai revolusi Syah Iran, sistem pemakaian pronomina untuk menunjukkan jati diri seseorang dan orang lain dalam suatu tindak tutur merupakan hal yang jelas. Dengan kata lain, bentuk pronomina merupakan cara pengacuan yang paling utama (Keshavars 1988). Secara ringkas dapat dikatakan bahwa pemakaian bentuk sapaan untuk menyatakan tingkat tutur dalam suatu bahasa mengacu kepada dua pola, yaitu merendahkan diri penutur (self-lowering) dan meninggikan mitra tutur (other raising). Gu (1990), sebagaimana dikutip dalam Wilian (1995), menyebut pola ini sebagai bidal penyapaan (address maxim), yang berbunyi 'panggillah mitra tutur Anda dengan sebutan yang pantas'.

Jika dilihat dari aspek kesantunan, tingkat tutur dapat diteropong dengan teori kesantunan berbahasa oleh Brown dan Levinson (1987) ataupun Leech (1983). Pada intinya mereka berbicara tentang masalah strategi bagaimana agar penutur dan petutur tidak kehilangan muka pada saat berkomunikasi dengan berpegang pada aturan sosial yang ada pada masyarakat tutur yang bersangkutan. Dari aspek komunikasi etnografi, tingkat tutur juga dapat ditinjau dari konsep Hymes (1972) yang juga berkaitan erat dengan kesantunan. Dia mengajukan delapan komponen, yang disebutnya komponen wicara (components of speech), yang berpengaruh pada pemilihan kode dalam bertutur. Kedelapan komponen itu kemudian diringkasnya dalam akronim yang mudah dihafal secara mnemonik, yaitu SPEAKING (Settings, Participants, Ends, Act Sequences, Keys, Instrumentalities, Norms, dan Genres).

\section{Bentuk Tingkat Tutur dalam Bahasa Sasak}

Pada umumnya, bagi masyarakat kebanyakan di Lombok, hanya dikenal dua bentuk bahasa dalam komunikasi sehari-hari, yaitu yang disebut dengan bahasa Sasak biase/jamaq atau aok-ape (ya-apa) dan Sasak alus atau tiangenggih (saya-ya). Adapun bahasa Sasak sangat halus, yang disebut kaji-meran (saya-ya), hanya dipakai oleh para datu-raden (raja dan kaum perwangsa atau ningrat). Klasifikasi itu didasarkan pada stratifikasi sosial masyarakat Sasak sebagai bangsawan atau menak (perwangsa) dan bukan bangsawan atau nonmenak (Syahdan 2000: 99-109). Faktor yang menyebabkan pemilihan terhadap bentuk bahasa yang digunakan, seperti juga dalam bahasa lain, adalah usia, status sosial, pendidikan, tingkat keakraban, situasi percakapan, jenis percakapan (formal/informal).

Seperti pada banyak bahasa yang lain, umumnya tingkat tutur dalam bahasa Sasak menggunakan bentuk pronomina yang berbeda-beda untuk 
menunjukkan perbedaan rasa hormat. Di samping itu, juga dipakai kata kerja, kata benda, dan kata sifat yang berbeda untuk menyebut $\mathrm{O} 1$ dan $\mathrm{O} 2$ atau O3 dalam tingkat tuturnya, namun jumlahnya itu sangat terbatas. Dalam praktiknya, kata-kata halus itu kebanyakan hanya dikenal oleh para "priayi" Sasak serta kaum bangsawan. Hal yang lazim lainnya, untuk menunjukkan perbedaan rasa hormat bagi kebanyakan rakyat biasa, selain bentuk bahasa halus melalui penggunaan bentuk-bentuk pronomina, juga dikenal beberapa kata tugas semacam partikel silaq atau ngiring 'silakan' dan kata penunjuk niki atau nike untuk 'ini/itu'. Bentuk pronomina dalam bahasa Sasak adalah sebagai berikut.

TABEL 1 BENTUK PRONOMINA

\begin{tabular}{|c|c|c|c|c|}
\hline & $\begin{array}{c}\text { O1 } \\
\text { (Orang pertama) }\end{array}$ & \multicolumn{2}{|c|}{$\begin{array}{c}\mathrm{O} 2 \\
\text { (Orang kedua) }\end{array}$} & $\begin{array}{c}\mathrm{O} 3 \\
\text { (Orang ketiga }\end{array}$ \\
\hline Tunggal pria (biasa) & \multirow{2}{*}{ Aku } & Ante & \multirow{2}{*}{ Kamu } & \multirow{2}{*}{ ie/nie } \\
\hline Tunggal wanita (biasa) & & Кати & & \\
\hline Tunggal (alus) & tiang & \multicolumn{2}{|c|}{ Side } & \\
\hline Tunggal honorific & Kaji & \multicolumn{2}{|c|}{$\begin{array}{c}\text { pelinggih/plungguh } \\
\text { dekaji }\end{array}$} & Deside \\
\hline Jamak inklusif & Ite & & & \\
\hline Jamak eksklusif & Kami & & & \\
\hline
\end{tabular}

Dalam tabel di atas terlihat bahwa bentuk pronomina orang pertama ada tiga: aku, tiang dan kaji. Bentuk pronomina $\mathrm{O} 2$ ada lima: ante, kamu, side, plinggih/plungguh dan dekaji. Namun, bentuk kaji 'saya' dan dekaji 'Anda' sudah sangat jarang sekali dipakai. Bagi sebagian besar dialek Sasak di Lombok, bentuk pronomina orang kedua tunggal dibedakan antara O2 laki ante dan O2 wanita kamu untuk bahasa biasa, sedangkan untuk menyatakan hormat kepada $\mathrm{O} 2$, orang yang dituakan atau orang yang belum dikenal umumnya digunakan kata side (namun bukan bentuk netral) atau kadang-kadang plinggih atau plungguh (untuk yang lebih dihormati) baik laki maupun perempuan seperti pada tuturan uaq 'paman' terhadap naken 'keponakan' berikut (dalam dialek ngeno-ngene dan meno-mene).

(1) Uaq : : Mek* lalo jok mbe atau mbe jaq melaiq (meq laiq)? 'Kamu (laki) mau ke mana?'

Naken : Ku lalo jok bale(n) papuq Ramiah atau Jaq kulalo jok balen papuq Ramiah.

'Saya mau ke rumah nenek Ramiah.'

* Catatan: Kata meq/bi merupakan bentuk lain dari anta/kamu dalam kalimat tanya dan menyangkal dalam bahasa Sasak biasa dialek Ngeno-Ngene. 
Tuturan uaq dan naken pada kalimat di atas merupakan bentuk bahasa Sasak biase. Uaq menggunakan mek 'kamu' dan lalo 'pergi' kepada keponakannya (naken), yang lebih muda. Namun, bila lawan tutur adalah orang yang lebih tua, dituakan, atau dihormati, seperti naken terhadap uaq, naken akan menyapa dengan pronomina da dari kata side:

(2) Naken : Da lalo jok mbe atau Mbe jaq de laiq?

Uaq $\quad:$ Ku lalo jok bale(n) papuq Ramiah atau Jaq kulalo jok balen papuk Ramiah.

Naken menggunakan pronomina da (dari kata side) kepada uaq dan uaq pun juga menjawab dalam bentuk biasa. Akan tetapi, pertanyaan naken dapat berubah bila yang dilawan bicara adalah orang yang dihormatinya, misalnya seorang guru atau ustad. Tuturan naken dapat berubah menjadi

(3) Naken : Pelinggih lalo jok mbe? atau Mbe plinggih lai?

Guru : Tiang lalo jok bale(n) papuk Ramiah.

Dalam tingkatan yang lebih halus lagi naken dapat mengganti kata kerja lai/lalo dengan kata lumbar jika, misalnya, ia berbicara kepada atau ditujukan kepada seorang yang sangat dihormati, seperti kepada kiai (ahli agama atau guru yang sangat dihormati) dalam contoh berikut.

(4) Naken

Kiai
: Mbe plinggih lumbar?

'Ke mana Anda hendak pergi?' (lit.)

: Tiang lalo jok pegedengan papuq Ramiah.

Digunakannya kata-kata halus pelinggih 'Anda' pada (3) dan lumbar 'pergi' pada (4), alih-alih lalo, menunjukkan bahwa naken ingin menyatakan rasa hormatnya kepada kiai dan kiai pun dapat menetralkan bentuk kepatutan ujarannya dengan menggunakan pronomina tiang 'aku' sebagai respons terhadap penghormatan naken. Di samping itu, kiai menambah bentuk hormat (honorific) pegedengan, alih-alih bale 'rumah', untuk menunjukkan bahwa orang yang akan dikunjungi bukan sembarangan, artinya ia adalah orang yang dihormati dan karena itu kata pegedengan digunakan untuk mengganti kata bale. Dalam hal ini naken dan kiai menggunakan bahasa Tinggi atau krama inggil', bila meminjam istilah tingkat tutur bahasa Jawa. Penggantian kata bale dengan pegedengan yang diacu kepada $\mathrm{O} 3$ yang dihormati, oleh Clynes (1994), disebut bentuk hormat O3 (Honorific+1sg).

Dalam suatu keluarga menak yang biasa menggunakan bahasa alus pun peristiwa tutur seperti pada (4) lazim ditemukan. Bila mamiq kake (Mk), sebutan untuk kakak laki-laki ayah atau ibu, pada keluarga bangsawan menanyakan kepada puterinya, baiq ijah 'Di mana kamu letakkan korek Ijah?', dia akan berujar seperti 
(5) Mk : Mbe taoq da toloq colok sino Ijah?

'Dimana tempat kamu letakkan korek itu Ijah?' (lit.)

Ijah : Nike leq atas meja deket jendela.

'Di situ di atas meja dekat jendela.'

Di sini mamiq kake menggunakan da/side 'kamu' kepada puterinya, bukan bi untuk memperhalus ujarannya, dan baiq ijah pun harus menjawab halus pula dengan menggunakan kata tugas nike 'di situ / di sana' dan bukan to atau tono. Adapun bentuk pronomina $\mathrm{O} 2$ dekaji dan $\mathrm{O} 3$ deside sudah hampir tak terdengar lagi dalam komunikasi sehari-hari kecuali pada acara-acara pesta adat perkawinan dalam kepembayunan atau sorong serah dan pembacaan cerita-cerita kisah nabi yantg disebut bekesah yang diterjemahkan dari Arab Melayu ke bahasa Sasak.

Berdasarkan contoh (1) - (5) tersebut, dapat dikatakan bahwa bahasa Sasak mengenal juga adanya tingkat tutur. Dalam contoh di atas O1 dan O2 menggunakan bentuk kata pronomina, kata benda, dan kata tugas yang berbeda untuk situasi, konteks, dan lawan bicara yang berbeda pula. Sebagaimana pada bahasa Jawa, Bali, Madura dan Sunda, tingkat tutur dalam bahasa Sasak dapat pula dinyatakan dengan sejumlah kata halus pada kata kerja, kata benda, kata sifat, dan kata tugas. Namun, jumlah semua kata halus ini sangat terbatas jika dibandingkan dengan kata halus bahasa Jawa. Di samping itu, pemakaiannya di kalangan masyarakat biasa pun sangat jarang terdengar, kalaupun dipakai masih terbatas hanya beberapa kata saja. Hal ini sangat berbeda dengan tingkat tutur dalam bahasa Jawa yang hampir semua lapisan masyarakatnya, setidak-tidaknya berdasarkan pengamatan saya, mengetahui hampir semua bentuk tingkat tutur atau sedikitnya mengetahui kosakata krama dari kosakata ngoko dan menggunakannya dalam hampir setiap kesempatan peristiwa tutur (lihat misalnya analisis percakapan antara pedagang dan pembeli di pasar dalam Rahardi 2001; Poedjasoedarma 1979; atau Geertz dalam Fishman 1968).

Beberapa contoh dari kosakata biasa yang mempunyai padanan kosakata halus dan sedang dalam bahasa Sasak tersebut adalah sebagai berikut. 
TABEL 2 CONTOH KOSAKATA BIASA, SEDANG, DAN HALUS

\begin{tabular}{|c|c|c|c|c|}
\hline Kategori & Biasa & Sedang & Halus & Indonesia \\
\hline Kt. Benda & $\begin{array}{l}\text { anaq } \\
\text { bale } \\
\text { mate } \\
\text { ime } \\
\text { snine } \\
\text { tian } \\
\text { kelambi,tangkong } \\
\text { aran } \\
\text { gigi } \\
\text { semame }\end{array}$ & $\begin{array}{l}- \\
- \\
\text { penenteng } \\
- \\
- \\
- \\
- \\
- \\
- \\
-\end{array}$ & $\begin{array}{l}\text { bije } \\
\text { pegedengan } \\
\text { penyerminan } \\
\text { gading } \\
\text { sbiniqan } \\
\text { bosang } \\
\text { kuace } \\
\text { pasengan } \\
\text { pageran } \\
\text { selakiq, selakiqan }\end{array}$ & $\begin{array}{l}\text { anak } \\
\text { rumah } \\
\text { mata } \\
\text { tangan } \\
\text { isteri } \\
\text { perut } \\
\text { baju } \\
\text { nama } \\
\text { gigi } \\
\text { suami }\end{array}$ \\
\hline Kt. Kerja & $\begin{array}{l}\text { tindoq/tendoq } \\
\text { lalo } \\
\text { mandiq } \\
\text { mele } \\
\text { mentelah } \\
\text { tokol } \\
\text { dateng } \\
\text { ngeraos } \\
\text { badaq } \\
\text { mangan }\end{array}$ & $\begin{array}{l}\text { begelaq } \\
- \\
- \\
- \\
- \\
- \\
- \\
- \\
\text { bekelor }\end{array}$ & $\begin{array}{l}\text { mesare,mensare } \\
\text { lumbar, margi } \\
\text { siram, besiram } \\
\text { kayun } \\
\text { singgah } \\
\text { mlinggih } \\
\text { rauh } \\
\text { bebaos } \\
\text { atur, matur } \\
\text { medahar/meda- } \\
\text { ran, } \\
\text { majengan }\end{array}$ & $\begin{array}{l}\text { tidur } \\
\text { pergi } \\
\text { mandi } \\
\text { ingin, mau } \\
\text { mampir } \\
\text { duduk } \\
\text { datang } \\
\text { berbicara } \\
\text { b e r i t a h u, } \\
\text { memberitahu } \\
\text { makan }\end{array}$ \\
\hline Kt. Sifat & $\begin{array}{l}\text { toaq } \\
\text { tedoq }\end{array}$ & $\begin{array}{l}- \\
-\end{array}$ & $\begin{array}{l}\text { lingsir } \\
\text { meneng }\end{array}$ & $\begin{array}{l}\text { tua } \\
\text { diam }\end{array}$ \\
\hline Kt. Tugas & $\begin{array}{l}\text { ne, sine } \\
\text { no, sino } \\
\text { wah } \\
\text { nteh, aneh } \\
\text { atao, atawe } \\
\text { araq } \\
\text { ndeq/ndeq araq } \\
\text { leq te } \\
\text { apa } \\
\text { aoq } \\
\text { kembeq, kumbeqna }\end{array}$ & $\begin{array}{l}- \\
- \\
- \\
\text { silaq } \\
- \\
- \\
- \\
- \\
- \\
-\end{array}$ & $\begin{array}{l}\text { niki } \\
\text { nike } \\
\text { sampun } \\
\text { ngiring, dawek } \\
\text { utawi } \\
\text { enten } \\
\text { nenten } \\
\text { leq niki, driki } \\
\text { napi } \\
\text { nggih } \\
\text { napi mawanan }\end{array}$ & $\begin{array}{l}\text { ini } \\
\text { itu } \\
\text { sudah } \\
\text { silahkan } \\
\text { atau } \\
\text { ada } \\
\text { tidak ada } \\
\text { di sisni } \\
\text { apa } \\
\text { ya } \\
\text { kenapa } \\
\end{array}$ \\
\hline
\end{tabular}

Gambaran tentang kosakata bahasa Sasak selengkapnya dan kemungkinan adanya kata seasal (kognat/cognate) dari kosakata halus tersebut dalam bahasa Jawa dan Bali dapat dilihat pada Lampiran 2 tulisan di akhir ini. Berdasarkan tulisan Clynes (1994) dan Steven (1965) dalam Nothofer (2000: $57-84)$, perbandingan jumlah kata tersebut adalah sebagai berikut. 
TABEL 3 PERBANDINGAN JUMLAH KATA HALUS

BAHASA JAWA, BALI, MADURA, DAN SASAK

\begin{tabular}{|c|c|c|c|c|}
\hline Bentuk bahasa & Jawa & Bali & Madura & Sasak \\
\hline Rendah & $\begin{array}{c}580 \text { (Clynes 1994) } \\
\text { Stevens (1965) tidak } \\
\text { menyebutkan }\end{array}$ & 480 & $\begin{array}{c}\text { Stevens (1965) } \\
\text { tidak menye- } \\
\text { butkan }\end{array}$ & 80 \\
\hline Sedang & 63 & 0 & 31 & 4 \\
\hline Tinggi & $\begin{array}{c}580 \text { (Clynes) } \\
600 \text { (Stevens) }\end{array}$ & 480 & 100 & 75 \\
\hline Hor -1 sg & 190 & 240 & 140 & 10 \\
\hline Hor +1 sg & 20 & 40 & Tidak ada data & 4 \\
\hline
\end{tabular}

\section{Arti dan Sejarah Tingkat Tutur}

Menurut analisis Nothofer (2000), bahasa Sasak mempunyai sistem tingkat tutur yang sama terperinci dan rumitnya dengan bahasa Jawa, Bali, dan Madura. Pendapatnya itu didasarkan pada perbandingan kalimat dan daftar sejumlah kata yang dipakai baik dalam bahasa Jawa maupun bahasa Bali seperti dapat dilihat pada akhir tulisan ini. Di samping itu, Nothofer (2000), yang mengambil referensi dari tulisan Errington (1983) dan Clynes (1994), menelusuri asal-usul kosakata halus dalam bahasa Sasak itu berdasarkan fakta sejarah kontak budaya Jawa, Bali, dan Lombok. Hubungan antara Jawa dan Bali secara kebudayaan berlangsung antara abad ke-8 dan abad ke-15 dan pengaruh Jawa itu sangat terlihat pada Hindu Bali. Namun, kemudian, setelah masuknya Islam di Jawa hubungan tersebut berhenti pada kira-kira abad ke-15 dan menyebabkan kehancuran di pihak Hindu Majapahit.

Pertanyaannya bagi para pakar adalah apakah ada bukti-bukti dalam naskah Jawa abad ke-15 yang dapat menunjukkan ke arah hubungan kebahasaan tersebut dan bagaimana kemudian bahasa halus itu berpengaruh sampai ke Lombok. Namun, yang jelas, Bali memang berada di Lombok selama dua abad lebih, abad ke-16 hingga ke-17 sebelum Belanda masuk. Apakah kemudian kontak bahasa halus itu terjadi pada saat "pendudukan" itu ataukah memang sebelumnya sudah ada kosakata halus terbentuk pada setelah Majapahit menguasai Lombok pada abad ke-14 dan pada tahap berikutnya menyebarkan agama Islam pada abad ke-16.

Menurut Nothofer, sistem tindak tutur bahasa Sasak terdiri dari dua subsistem, sistem bentuk (style system) dan sistem referensi/acuan (reference system). Ketiga bahasa-Jawa, Bali, dan Sasak-membedakan tiga bentuk tindak tutur: rendah (low), netral (mid), dan tinggi (high). Pemakaian tiap-tiap bentuk ini ditentukan oleh hubungan antara penutur dan petutur, status sosial, dan tingkat keakraban peserta tutur.

Sistem acuan digunakan untuk menyatakan penghormatan (deference) kepada seseorang yang mungkin menjadi orang kedua atau ketiga dalam percakapan. Dalam sistem ini kata-kata dibagi ke dalam dua subkelompok. Subkelompok pertama adalah kosakata yang mengacu kepada kepemilikan dan perbuatan atau tindakan (posessions and actions) dari seseorang yang sangat 
dihormati, sedangkan subkelompok kedua adalah kosakata yang mengacu kepada perbuatan yang diarahkan kepada orang yang juga sangat dihormati. Clynes (1994) menyebut subkelompok pertama dengan bentuk hormat orang ketiga (honorific-1sg), sedangkan yang kedua dengan bentuk hormat orang kedua (honorific $+1 s g$ ) karena kata-kata pada subkelompok pertama tidak pernah dipakai untuk orang pertama, sedangkan subkelompok kedua dapat saja mengacu kepada pembicara. Sistem bentuk dan sistem referensi ini ditandai oleh penggunaan kata-kata yang berbeda untuk menyatakan makna dasar yang sangat variatif. Selain itu, subkelompok sistem bentuk dan sistem referensi ini juga dinyatakan dengan penggunaan kata-kata yang menyatakan makna konotatif di samping makna denotatif.

Nothofer memberikan contoh tiga pilihan kata untuk mata, yaitu mate untuk tingkat rendah, penenteng untuk tingkat netral, dan penyerminan untuk tingkat tinggi. Bentuk pertama menyatakan hubungan keakraban antara penutur dan petutur, kedua menyatakan hubungan agak berjarak, dan ketiga untuk hubungan yang resmi dan sebagai bentuk penghargaan (honorific word). Sebagai contoh yang lain, kata memberi tahu atau katakan dalam bahasa Sasak rendah adalah badaq, yang mempunyai bentuk penghargaan HOR+1sg atur dan HOR-1sg ican. Atur menyatakan penghambaan (humble) dan ican menunjukkan penghormatan terhadap orang yang dituju. Dengan demikian, menurut Nothofer, bahasa Sasak mempunyai empat kelas kata yang berbeda yang oleh Clynes (1994) disebut attitudinal classes 'kelas penghargaan' karena kata-kata itu membawa makna status tambahan (Stevens 1965: 295, yaitu rendah (low), menengah (mid), tinggi (high), dan hormat (honorific), sedangkan kata-kata yang hanya mempunyai satu bentuk tidak membawa makna status.

Pembagian sistem tingkat tutur bahasa Sasak yang sama seperti tingkat tutur bahasa Jawa dan Bali oleh Nothofer didasarkan pada analisis tuturan pada ketiga bahasa dimaksud seperti pada contoh berikut ini. Dalam contoh ini dibentangkan bahwa bentuk pilihan yang sama terdapat juga dalam bahasa Jawa, Bali dan Sasak (hlm. 58). Misalnya untuk kalimat Bu Sastro sudah makan seperti berikut.

Bentuk rendah (low style):

$\begin{array}{llll}\text { Jawa : } & \begin{array}{l}\text { Bu Sastro } \\ \text { Netral }\end{array} & \begin{array}{l}\text { wis } \\ \text { Rendah }\end{array} & \begin{array}{l}\text { mangan. } \\ \text { Rendah }\end{array} \\ \text { Bali : } & \begin{array}{l}\text { Bu Sastra } \\ \text { Netral }\end{array} & \begin{array}{l}\text { suba } \\ \text { Rendah }\end{array} & \begin{array}{l}\text { madaar. } \\ \text { Rendah }\end{array} \\ & & & \\ \text { Sasak: } & \text { Bu Sastre } & \text { wah } & \text { mangan. } \\ & \text { Netral } & \text { Rendah } & \text { Rendah }\end{array}$

Tiap-tiap kalimat berisi elemen yang netral dengan dua kata yang 
dianggap rendah (low). Bentuk itu digunakan bila berbicara kepada seseorang yang secara sosial dianggap lebih rendah, anggota keluarga yang dianggap lebih muda, atau seseorang yang sangat dikenal dan akrab.

Bentuk menengah (mid style):

$\begin{array}{rlrr}\text { (7) Jawa : Bu Sastro } & \text { mpun } & \text { dhahar. } \\ & \text { Netral } & \text { Menengah } & \text { Hormat } \\ \text { atau } & \text { Bu Sastro } & \text { mpun } & \text { nedho. } \\ & \text { Netral } & \text { Menengah } & \text { Tinggi }\end{array}$

$\begin{array}{cll}\text { Bali : } & \text { ane } & \text { nike } \\ \text { Rendah } & \begin{array}{l}\text { Tinggi ajeng-a teken Bu Sastre } \\ \text { rel }\end{array} & \begin{array}{l}\text { Tinggi Tinggi-Rendah Rendah Netral } \\ \text { thatready eat-3ACT by }\end{array} \\ \text { Sasak: Bu Sastre } & \text { wah bekelor. } \\ \text { Netral } & \text { Rendah Menengah }\end{array}$

Tuturan (7) mengandung bentuk kata-kata menengah (mid) sehingga kalimatnya juga menengah. Dalam bahasa Jawa untuk menengah terbatas pada kata-kata tugas (functors), tetapi sering berhubungan secara fonemis dengan kata yang sama dalam bentuk rendah. Misalnya bagaimana dalam bahasa Jawa dinyatakan dengan kepriye (rendah), kepripun (menengah), kados pundi (tinggi). Dalam bahasa Sasak kata menengah tidak pernah sama dengan kata yang digunakan dalam bentuk rendah atau tinggi. Nothofer juga menyatakan bahwa bahasa Bali tidak mempunyai kosakata menengah yang berbeda, meskipun ia mempunyai bahasa bentuk menengah yang dicirikan oleh campuran bentuk kata-kata rendah dan tinggi seperti disebutkan dalam contoh tersebut. Dalam bahasa Jawa dan Sasak, bentuk menengah dicirikan oleh kehadiran paling tidak satu kata menengah dalam sebuah tuturan. Seperti juga dalam bahasa Bali, kalimat bentuk menengah dalam bahasa Jawa dapat mengandung bentuk tinggi dan menengah. Misalnya dalam kalimat Ibu Sastro sudah makan yang itu dalam bahasa Jawa seperti berikut.

$$
\begin{array}{llll}
\text { Jawa: } & \text { Bu Sastro } & \text { mpun nedha sing niku. } \\
\text { Netral } & \text { Menengah Tinggi } & \text { Rendah Menengah }
\end{array}
$$

Dalam bahasa Sasak, menurut Nothofer, pertemuan bentuk tinggi dan rendah, ketika hadir bentuk menengah dalam sebuah kalimat, tidak berterima atau dalam istilahnya tidak gramatikal, sebagaimana berikut.

$$
\begin{array}{llll}
\text { Sasak: } & { }^{* B u} \text { Sastre } & \text { sampun } & \text { bekelor. } \\
& \text { Netral } & { }^{*} \text { Tinggi } & \text { Menengah }
\end{array}
$$

Dalam bahasa Jawa bentuk tinggi dan rendah dapat secara bebas bertemu, seperti pada contoh (7), tetapi tidak untuk tuturan (10) dan (11) berikut. 
$(10)$

$\begin{array}{clll}\text { Jawa: } & \begin{array}{c}{ }^{*} \text { Bu Sastro } \\ \text { Netral }\end{array} & \begin{array}{l}\text { wis } \\ \text { Rendah }\end{array} & \begin{array}{l}\text { nedha. } \\ \text { *Tinggi }\end{array} \\ \text { Jawa: } & \text { *Bu Sastro } & \begin{array}{l}\text { sampun } \\ \text { Tinggi }\end{array} & \begin{array}{l}\text { mangan. } \\ \text { *Rendah }\end{array}\end{array}$

Bentuk menengah sering digunakan bila hubungan status penutur dan petutur belum jelas atau bila jarak sosial di antaranya sama. Dalam bahasa Sasak bentuk ini juga digunakan terhadap saudara yang lebih tua dan terhadap orang tua.

Bentuk tinggi (high style):

$\begin{array}{llll}\text { Jawa: } & \begin{array}{l}\text { Bu Sastro } \\ \text { Netral }\end{array} & \begin{array}{l}\text { sampun } \\ \text { Tinggi }\end{array} & \begin{array}{l}\text { nedho. } \\ \text { Tinggi }\end{array} \\ \text { Bali: } & \begin{array}{l}\text { Bu Sastre } \\ \text { Netral }\end{array} & \begin{array}{l}\text { sampun } \\ \text { Tinggi }\end{array} & \begin{array}{l}\text { ngajeng. } \\ \text { Tinggi }\end{array} \\ & & & \\ \text { Sasak } & \text { Bu Sastre } & \text { sampun } & \text { medaran (medahar). } \\ & \text { Netral } & \text { Tinggi } & \text { Tinggi }\end{array}$

Pada ketiga bahasa, bentuk tinggi digunakan untuk menunjukkan jarak dan rasa hormat serta derajat keformalan kepada seseorang yang dihadapi oleh penutur. Di samping itu, bentuk kata hormat juga dapat digunakan pada setiap bentuk kalimat di atas. Hal ini dapat dilihat pada tuturan bahasa Sasak berikut.

\begin{tabular}{|c|c|c|c|}
\hline \multirow[t]{4}{*}{ Sasak: } & Bu Sastre & wah & $\begin{array}{l}\text { majengan. } \\
\text { makan } \\
H o n-1 \text { so }\end{array}$ \\
\hline & Netral & Rendah & Hon-1sg \\
\hline & Bu Sastre & $\begin{array}{l}\text { sampun } \\
\text { sudah }\end{array}$ & $\begin{array}{l}\text { majengan. } \\
\text { makan }\end{array}$ \\
\hline & Netral & Tinggi & Hon-1sg \\
\hline
\end{tabular}

Akan tetapi, dalam contoh ini tidak ditemukan bentuk menengah karena memang kata bahasa Sasak dalam kategori ini sangat sedikit. Berdasarkan data yang diperoleh, perbedaan yang paling penting antara bahasa Jawa, Bali, dan Sasak dalam hal tingkat tutur, menurut Nothofer, adalah penutur dalam bahasa Sasak tidak diperkenankan memilih selain kata-kata rendah (low words) bila mengacu kepada perbuatan dan kepemilikan sendiri (Nothofer, 2000: 60) sebagaimana dicontohkan dalam kalimat bahasa Sasak berikut. 
(14a) Rendah: Aku wah mangan kamu ndeqman mangan. 1sg sudah makan 2sg belum makan

Rendah Rendah Rendah Rendah Rendah Rendah

(14b) Menengah: $A k u$ wah mangan side ndeq man bekelor. Rendah Rendah Rendah Menengah Rendah Menengah

(14c) Tinggi: Sampun tiang mangan pelinggih nenten man medaran. Tinggi Tinggi Rendah Tinggi Tinggi Tinggi

(14d) Tinggi: Sampun kaji mangan dekaji nenten man majengan. Hon. Tinggi Hon+1sg Rendah Hon-1sg Tinggi Hon-1sg

Dari data itu Nothofer menunjukkan bahwa banyak persamaan antara bahasa Jawa, Bali, dan Sasak dari segi sistem bentuk (style system), meskipun kesamaan bahasa Jawa dan Bali lebih banyak daripada dengan bahasa Sasak. Keduanya sama-sama menggunakan kosakata tinggi yang mengacu perbuatan dan kepemilikan penutur. Selain itu, secara kuantitatif keanggotaan kosakata rendah, tinggi, dan sedang dalam bahasa Jawa dan Bali sangat mirip, sedangkan bahasa Sasak hanya menggunakan kosakata rendah untuk menyatakan tindakan dan kepemilikan penutur. Di samping itu, bahasa Sasak mempunyai bentuk rendah yang jauh lebih banyak pada setiap kelas katanya daripada dengan bahasa Jawa dan Bali seperti terlihat pada Tabel 3.

\section{Komentar dan Analisis terhadap Pandangan Nothofer}

Dari korpus data yang berupa kalimat Bu Sastro sudah makan dan Aku sudah makan, kamu belum makan tampaknya pandangan Nothofer yang menyatakan bahwa tingkat tutur bahasa Sasak sama terinci dan sama rumitnya dengan bahasa Jawa belum dapat dianggap tepat. Beberapa hal yang saya ajukan sebagai tentangan atas perampatan Nothofer itu adalah sebagai berikut.

Pertama, kosakata halus (krama dalam bahasa Jawa) dalam bahasa Sasak sangat terbatas yang terdapat pada bentuk pronomina dan pada beberapa kata benda serta kata kerja. Hal ini jelas berbeda dengan bahasa Jawa, yang mempunyai bentuk halus (krama) pada hampir semua bentuk kata, tak terkecuali kata bilangan, kata penghubung, kata depan, bahkan sampai pada kata berimbuhan. Menurut Pudjasoedarma, jumlah kosakata krama kira-kira 850-an. Dalam bahasa Sasak tidak pula ditemukan bentuk halus pada kata bilangan sebagaimana ditemukan pada bahasa Jawa. Tabel berikut menjadi sekadar contoh bahwa dalam bahasa Sasak tidak ditemukan bentuk krama seperti yang terdapat dalam bahasa Jawa. 
TABEL 4 PERBANDINGAN KOSAKATA PADA BAHASA JAWA DAN SASAK

$\begin{array}{llll}\text { Jawa } & & \text { Sasak } & \\ \text { Ngoko } & \text { Krama } & \text { Biasa } & \\ \text { siji } & & & \\ \text { loro } & \text { - stunggal } & \text { sekeq 'satu' } \\ \text { telu } & \text { - skaleh } & \text { dua 'dua } \\ \text { papat } & \text { - tigo } & \text { telu 'tiga } \\ \text { lima } & \text { - sekawan } & \text { mpat 'empat' } \\ \text { yst } & \text { - gangsal } & \text { lima/e 'lima }\end{array}$

Pembentukan kata krama dalam bahasa Jawa juga dapat dilakukan melalui proses perubahan morfofonemis dari kata-kata ngoko. Hal sejenis tidak terdapat dalam bahasa Sasak. Dalam kosakata bahasa Jawa, menurut Poedjasoedarma (1979), kata krama dapat digolong-golongkan ke dalam dua kelompok menurut bentuk fonemisnya. Kelompok yang pertama adalah kata krama yang bentuknya sama sekali berbeda dengan padanan ngoko-nya, misalnya kula-aku 'saya', griya-omah 'rumah', tilem-turu 'tidur', weruh-sumerep 'melihat, tahu', dan gedhe-ageng 'besar'. Kelompok yang kedua adalah kata krama bahasa Jawa yang menyerupai bentuk ngoko-nya, misalnya

$\begin{array}{lll}\text { ganti } & \text { gantos } & \text { 'ganti' } \\ \text { rasa } & \text { raos } & \text { 'rasa' } \\ \text { dandan } & \text { dandos } & \text { 'dandan' } \\ \text { kira } & \text { kinten } & \text { 'kira' } \\ \text { pira } & \text { pinten } & \text { 'berapa' } \\ \text { mlebu } & \text { mlebet } & \text { 'masuk' } \\ \text { murah } & \text { mirah } & \text { 'murah' } \\ \text { dll. } & & \end{array}$

Daftar itu ditampilkan hanya untuk menyebut beberapa contoh saja. Proses morfologis dan fonemis ini mirip dengan sistem perubahan kata kerja yang tidak beraturan (irregular verbs) dalam bahasa Inggris. Sebaliknya, proses perubahan kata yang sama tidak ditemukan dalam kata-kata bahasa Sasak.

Kedua, pemakaian tingkat tutur bahasa Sasak yang "terinci dan rumit" itu tidaklah begitu meluas pemakaiannya dalam semua lapisan masyarakat di Lombok, setidaknya dalam lingkungan tempat asal saya di Lombok. Masyarakat biasa hanya mengenal beberapa kata dari kosakata halus, baik kata kerja, kata benda, maupun kata sifat yang ada. Kalimat contoh yang diberikan oleh Nothofer, yaitu Bu Sastro sudah makan, merupakan bentuk kata dan struktur kalimat yang setara dengan dan kemungkinan berasal dari (pengaruh) bahasa Jawa. Contoh itu sepadan dengan contoh (4) dan (5) sebelumnya. 
Ketiga, korpus data yang diambil dari perbandingan bentuk kata-kata tugas (sebab, itu-ini), pronomina (aku-kamu), nomina waktu sekarang, serta interogativa apa, mengapa, dan lain-lain, yang masing-masing dioposisikan oleh Nothofer untuk menyatakan rendah (low), tinggi (high), atau halus-kasarnya serta santun-tidaknya kata tersebut merupakan contoh yang tidak semua diketahui oleh lapisan masyarakat Sasak di Lombok. Pada umumnya kosakata halus dipakai oleh mereka yang disebut kaum pedaleman untuk menyebut orang yang berada di sekitar kompleks Datu-Raden atau kaum ningrat di Lombok. Tentu banyak faktor yang menyebabkan kosakata halus itu tidak sampai pada semua lapisan masyarakat. Di antaranya adalah kemungkinan latar belakang sejarah kerajaan-kerajaan di Lombok pada masa lampau yang tidak terpusat sehingga juga menyebabkan adanya berbagai dialek dan logat bahasa Sasak itu sendiri.

Selanjutnya, Nothofer juga membandingkan sebanyak 15 kata benda, 10 kata tugas, 2 kata sifat, dan 29 kata kerja sebagaimana terlihat pada Bagan 2 dalam Lampiran tulisan ini, yang masing-masing mempunyai oposisi biner kesantunan. Data itu, semuanya, sama dengan yang ada dalam bahasa Jawa. Beberapa contoh kata tersebut adalah sebagai berikut.

$\begin{array}{llll} & \text { Bahasa Sasak } & \text { Bahasa Jawa } & \\ & \text { wah } & \text { sampun } & \text { 'sudah' } \\ \text { atao } & \text { utawi } & \text { 'atau' } \\ \text { Kata tugas } & \text { nane/nani } & \text { mangkin } & \text { 'sekarang' } \\ & \text { pade } & \text { sami } & \text { 'sama' } \\ \text { aku } & \text { tiang/kaji (hon.) } & \\ & \text { dll. } & & \\ & \text { mate } & \text { penenteng/penyerminan (hon.) } & \text { 'mata' } \\ & \text { mame } & \text { laki } & \text { 'laki-laki' } \\ \text { Kata benda } & \text { senine } & \text { sebiniq } & \text { 'istri' } \\ & \text { gigi } & \text { pageran } & \text { 'gigi' } \\ & \text { dll. } & & \\ \text { Kata sifat } & \text { tedoq } & \text { meneng } & \text { 'diam' } \\ & \text { toaq } & \text { lingsir } & \text { 'tua' } \\ & \text { lalo } & \text { lumbar/margi (Hon.) } & \text { 'pergi' } \\ \text { Kata kerja } & \text { mangan } & \text { bekelor/medahar (Hon.) } & \text { 'makan' } \\ & \text { ngeraos } & \text { bebaos } & \text { 'nerbicara' } \\ & \text { mentelah } & \text { singgah } & \text { 'mampir' } \\ & \text { dll. } & & \end{array}$

Berdasarkan perbandingan kosakata ngoko dan krama dalam bahasa Sasak dan bahasa Jawa ini kemudian dianalisis satu per satu asal-usul katanya (etimologinya). Selanjutnya, disimpulkannya bahwa bahasa Sasak sama dengan bahasa Jawa dalam hal kerumitan dan kekompleksan tingkat tuturnya. Pertanyaannya adalah dapatkah dirampatkan bahwa bahasa Sasak sama "rumit" dan "kompleks" dengan bahasa Jawa atau bahasa Bali hanya berdasarkan dua atau tiga contoh kalimat seperti kalimat (6) - (14) di muka serta daftar kosakatanya? Tampaknya masih terlalu dini untuk 
bisa menyimpulkannya demikian karena, dari sudut pandang pendekatan sosiolinguistik, struktur bahasa dalam suatu masyarakat bukan merupakan sesuatu yang sama sekali seragam, homogen atau monolitik, melainkan bervariasi yang berkorelasi dengan perbedaan-perbedaan sistem sosial masyarakat tutur bersangkutan (Bright 1966). Sebagai penutur bahasa Sasak yang juga mengetahui dan menggunakan bahasa Jawa, saya menganggap tingkat tutur bahasa Jawa masih terlalu rumit untuk dibandingkan dengan bahasa Sasak. Bukan saja karena kosakata bahasa Jawa yang begitu luas dan kompleks, melainkan juga karena pemakaiannya yang menuntut penutur dan petutur untuk waspada pada setiap situasi peristiwa tindak tutur itu sendiri sehingga yang satu tidak sampai dicap "bukan Jawa" oleh yang lain.

Berbeda halnya dengan bahasa Sasak, hampir semua tingkatan tutur bahasa Jawa, menurut pengamatan saya, juga dikuasai dan digunakan oleh hampir semua lapisan masyarakat pada hampir setiap peristiwa tindak tutur sehari-hari, paling tidak diselipi beberapa kosakata krama. Hal ini sangat berbeda dengan bahasa Sasak. Tidak semua orang Sasak menguasai bentukbentuk halus berupa penghormatan dalam bahasa Sasak, lebih-lebih mereka yang tidak berasal dari golongan yang disebut menak atau bangsawan. Itulah sebabnya, banyak orang tidak mengetahui penggunaan bentuk hormat margi, parek, dan lumbar sebagaimana dinyatakan Azhar (1996) dalam tuturan berikut.

(15a) Silaq meno, tiang margi juluq! 'kalau begitu, saya mohon diri dulu!'

(15b) Piran pelungguhda parek malik? 'kapan Anda akan datang lagi?'

(15c) Tiang lumbar ojok Lembar lemaq kelemaq! 'saya akan pergi ke Lembar besok pagi!'

Kata-kata margi 'pergi', parek'datang' dan lumbar' pergi' jelas maksudnya digunakan untuk menunjukkan rasa hormat kepada orang yang diajak bicara. Namun, yang terjadi justru sebaliknya, dia meninggikan dirinya sendiri karena kesalahan menempatkan kata halus bentuk hormat O2 itu, yang seharusnya berfungsi meninggikan lawan tutur. Kalimat tersebut seharusnya berbunyi

(16a) Silaq meno, tiang lalo juluq! atau

Silaq meno, tiang pamit juluq!

(16b) Piran plungguhda rauh malik (malih)? atau

Piran plungguhda gen lumbar malik (malih)?

(16c) Tiang lalo ojok Lembar lemaq kelemaq! atau

Gen tiang lalo aning Lembar jemaq kelemaq!

Dalam perkembangan bahasa Sasak, sekarang dapat dikatakan bahwa orang biasa hanya mengetahui beberapa saja dari kata halus yang ada, yang terbatas pada kata tugas dan pronomina serta beberapa kata kerja dan kata benda seperti disebutkan di atas. Apakah kemudian bentuk ini merupakan 
pengaruh bahasa halus dari bahasa Jawa dan Bali ataukah sesuatu yang merupakan local genius? Kelihatannya masih harus diselidiki. Sebagai bahan perbandingan dengan tingkat tutur bahasa Jawa, bahasa Sasak tidak mengenal tingkatan berikut seperti dalam bahasa Jawa, sebagaimana dikutip dalam Holmes (1992: 273; Geerts dalam Hymes, 1969: 284). Kalimat Mengapa kamu mengambil nasi sebanyak itu? dapat dibuat menjadi beberapa tingkatan sebagai berikut.

$\begin{array}{lllll}\text { Menapa } & \text { nandalem } & \text { mundhut } & \text { sekul } & \text { semanten ? TINGGI } \\ \text { Menapa } & \text { panjenengan } & \text { mendhet } & \text { sekul } & \text { semanten? } \\ \text { Napa } & \text { sampeyan } & \text { njupuk } & \text { sega } & \text { semonten? } \\ \text { Apa } & \text { sliramu } & \text { mundhut } & \text { sega } & \text { semono? } \\ \text { Apa } & \text { kowe } & \text { njupuk } & \text { sega } & \text { semono? RENDAH }\end{array}$

Pada tingkatan yang paling tinggi krama inggil semua kata adalah untuk halus ' krama'. Dalam kenyataannya pada bahasa Sasak bentuk seperti ini tidak ditemukan, paling tidak dalam dialek yang saya ketahui. Dengan demikian, agak sulit untuk menyatakan bahwa bahasa Sasak mempunyai speech level yang sama terperinci dan rumitnya dengan bahasa Jawa. Fakta bahwa bahasa Sasak mengenal beberapa kata halus seperti dicontohkan pada (1) - (14) adalah benar. Namun, menurut hemat saya, ini belum cukup untuk mengatakan bahwa bahasa Sasak mempunyai sistem tingkat tutur yang kompleks, sama dengan bahasa Jawa.

\section{Penutup}

Dalam setiap peristiwa tindak tutur dalam sejumlah bahasa, terutama bahasa di Asia, seorang penutur harus memilih beberapa alternatif bentuk bahasa dan kata yang akan digunakan untuk menyatakan kesopanan dan hormatnya kepada lawan tutur, yang ditentukan oleh faktor usia, perbedaan status sosial, pendidikan, kekerabatan, latar belakang keluarga, serta konteks percakapan. Begitu pula yang terdapat dalam bahasa Sasak. Ada konteks tertentu yang menyebabkan pemakaian bahasa alus dalam pengertian sopan (polite) dan hormat (deferential) serta bahasa jamak (sehari-hari/plain). Akan tetapi, saat ini sebagian masyarakat Sasak tidak menggunakan bentuk bahasa halus dari sebagian besar kata kerja dan kata benda yang ada pada bahasa ini, kecuali pada situasi yang sangat terbatas (dan resmi) dalam hubungan bawahan dengan atasan di kantor pemerintah atau di pondok pesantren dan di lingkungan keluarga bangsawan ataupun dalam acara prosesi perkawinan adat Sasak yang disebut acara sorong-serah. Namun, untuk mengetahui bagaimana sesungguhnya bahasa halus itu digunakan sampai sekarang dan sampai seberapa besar pengaruh kosakata halus bahasa Jawa dan bahasa Bali dalam bahasa Sasak tampaknya masih perlu penelitian mendalam. Yang jelas dapat disimpulkan bahwa dalam bahasa Sasak dikenal juga adanya sopan santun berbahasa, atau dapat pula disebut tingkat tutur atau undha usuk, sebagaimana juga dikenal dalam bahasa lain, meskipun tidaklah sedetail dan serumit yang diperkirakan orang. 
Ada yang berpendapat bahwa masyarakat penutur suatu bahasa yang tidak mengenal undha usuk dalam bahasanya dapat diinferensikan sebagai kurang mengenal kesantunan berbahasa. Namun, perlu diingat bahwa berbuat santun dalam setiap masyarakat tutur suatu bahasa itu berbeda-beda, sebagaimana dikatakan oleh Holmes (1992),

Being polite is a complicated business in any language. It is difficult to learn because it involves understanding not just the language, but also the social and cultural values of the community. We often don't appreciate just how complicated it is, because we tend to think of politeness simply as a matter of saying please and thank you in the right places. In fact it involves a great deal more than the superficial politeness routines that parents explicitly teach their children, .... .

Menjadi santun memang merupakan usaha yang susah-susah gampang dalam setiap bahasa. Dalam mempelajari kesantunan tidak hanya diperlukan pemahaman atas bahasa, tetapi juga nilai-nilai sosial budaya masyarakat pemilik bahasa itu. Sering kita tidak memikirkan kekompleksan bahasa itu karena cenderung berpendapat bahwa kesantunan tidak lebih dari sekadar mengucapkan salam monggo, silakan, dan terima kasih. Kesantunan mencakup lebih dari sekadar mempelajari rutinitas mengucapkan kata-kata itu yang sama nilainya dengan memelajari akhlak dan kepribadian.

\section{Daftar Acuan}

Azhar, Lalu Muhammad (1996), Reramputan Pelajaran Bahasa Sasak: untuk kls 3 SLTP. Klaten: PT Intan Pariwara

Brown, Roger dan Marguerite Ford (1964), “Address in American English”, dalam Dell Hymes (ed.), Language in Culture and Society: A Reader in Linguistics and Anthropology. New York: Harper and Row Publishers

Clynes, Adrian (1994), "Old Javanese influence in Balinese: Balinese Speech Styles", dalam Tom Dutton, Darrel T. Tryon (ed.), Language Contact and Change in the Austronesian World, hlm. 141-179. Berlin, New York: Mouton de Gruyter

Errington, J. (1983), "Speech in the Royal Presence: Javanese Palace Language”, dalam Indonesia 34: 89-101.

Geertz, Clifford (1968), "Linguistic Etiquette”, dalam Joshua A. Fishman (ed), Readings in the Sociology of Language, hlm. 282-295. Paris: Mouton \& Co. N.V. Publishers.

Haris, Tawaliuddin (2002). "Masuk dan Berkembangnya Islam di Lombok: Kajian Data Arkeologi dan Sejarah", dalam Kajian, Jurnal Pemikiran Sosial Ekonomi dan Daerah NTB, No. 01, Thn. I, Februari--Maret. Mataram: Yayasan Lentera Utama.

Holmes, Janet (1992), An Introduction to Sociolinguistics. New York: Longman Publishing.

Keshavarz, Mohammad Hosein (1988), "Forms of Address in Post-revolutionary Iranian Persian: A Sosiolinguistic Analysis", dalam Language in Society 17. 565-575.

Kridalaksana, Harimurti (1993), Kamus Linguistik. Jakarta: Gramedia Pustaka Utama

Martin, Samuel E. (1964), "Speech Levels in Japan and Korea", dalam Dell Hymes (ed.) Language and Culture in Society: A Reader in Linguistics and Anthropology. New York: Harper dan Row Publishers.

Nothofer, Bernd (2000), "A Preliminary Analysis of the History of Sasak Language Level”, dalam Peter K. Austin (ed.), Sasak:Working Papers in Sasak, Vol. 2., hlm. 57-84. Department of Linguistics and Applied Linguistics, The University of Melbourne.

Poedjosoedarmo, Soepomo et al. (1979), Tingkat Tutur Bahasa Jawa. Jakarta: Depdikbud.

Rahardi, R. Kunjana (2001), Sosiolinguistik, Kode dan Alih Kode. Yogyakarta: Pustaka Pelajar. Syahdan (2000), "Code-Switching in the Speech of Elite Sasaks", dalam Peter K Austin (ed.) 
Sasak: Working Papers in Sasak, vol. 2., hlm. 57-84. Department of Linguistics and Applied

Linguistics, The University of Melbourne.

Willian, Sudirman (1995), "Forms of address in Sasak", dalam Aksara. Denpasar: Pusat

Bahasa-Depdikbud Provinsi Bali.

LAMPIRAN 1

\section{BAGAN 1 BAHASA JEPANG STANDAR}

(1) Poros penyapaan:

\begin{tabular}{|l|l|l|l|}
\hline & \multicolumn{1}{|c|}{ BIASA } & \multicolumn{1}{c|}{ SOPAN } & \multicolumn{1}{c|}{ HORMAT } \\
\hline Kopula & dá & désu & - \\
\hline & $\begin{array}{l}\text { de áru } \\
\text { (formal) }\end{array}$ & $\begin{array}{l}\text { de arimásu } \\
\text { (formal) }\end{array}$ & de gozaimásu \\
\hline Bentuk Verba & $\ldots-(\mathrm{r}) \mathrm{u}$ & $\ldots(\mathrm{i})$-másu & - (gozaimásu) \\
\hline
\end{tabular}

(2) Poros pengacuan:

\begin{tabular}{|l|l|l|l|}
\hline & \multicolumn{1}{|c|}{ Kopula } & \multicolumn{1}{c|}{ Bentuk Verba } & \\
\hline MERENDAH & & o- $\ldots$-I suru & \\
\hline NETRAL & dá & $\ldots$-(r)u & \\
\hline MENINGGI & de irassyáru & o-...-I ni náru & \\
\hline
\end{tabular}

(3) Verba pemberian (donatory verbs) (gives):

\begin{tabular}{|l|l|l|l|}
\hline & & & \\
\hline MERENDAH & ageru & (out-giving) & \\
\hline NETRAL & $\begin{array}{l}\text { yaru } \\
\text { kureru (in-giving) }\end{array}$ & & \\
\hline MENINGGI & kudasáru & & \\
\hline
\end{tabular}

(4) Verba eufemistis:

\begin{tabular}{|l|l|l|l|}
\hline & \multicolumn{1}{|c|}{ 'does' } & \multicolumn{1}{c|}{ 'says' } & (etc.) \\
\hline MERENDAH & itasu & móosu & \\
\hline NETRAL & suru & iu & \\
\hline MENINGGI & nasáru & ossyáru & \\
\hline
\end{tabular}

BAGAN 2 BAHASA KOREA STANDAR

(1) Poros penyapaan: 


\begin{tabular}{|c|c|c|c|}
\hline & \multicolumn{3}{|c|}{ di dalam kelompok } \\
\hline & BIASA & AKRAB & KENAL \\
\hline & -ta & -na & $\begin{array}{c}\text {-e } \\
\text {-ci }\end{array}$ \\
\hline & \multicolumn{3}{|c|}{ di luar kelompok } \\
\hline & SOPAN & OTORITATIF & HORMAT \\
\hline & -e yo & -(s)o & -(su)p.nita \\
\hline
\end{tabular}

(2) Poros pengacuan:

\begin{tabular}{|l|l|l|l|}
\hline NETRAL & -ta & & \\
\hline MENINGGI & $-(\mathrm{u}) \mathrm{si}-$ & & \\
\hline
\end{tabular}

(3) Verba eufemistis:

\begin{tabular}{|l|l|l|l|}
\hline & 'eat' & 'sleep' & 'stay' \\
\hline NETRAL & mek- & ca- & iss- \\
\hline MENINGGI & capswu-(si-) & cwumusi & kēysi- \\
\hline
\end{tabular}

\section{LAMPIRAN 2}

Daftar kosakata bahasa Sasak yang termasuk attitudinal classes (kelas penghormatan) menurut Clynes (1994) yang didaftar oleh Nothofer dan saya susun kembali menurut dialek bahasa Sasak meno-mene dan ngeno-ngene. Kosakata ini kemungkinan berkognat dengan kosakata yang sama dalam bahasa Jawa atau bahasa Bali yang diberi tanda centang.

\begin{tabular}{|l|l|l|l|l|l|l|}
\hline \multicolumn{1}{|c|}{ Low } & Mid & \multicolumn{1}{c|}{ High } & BJ & BB & Honorific & \multicolumn{1}{|c|}{ Indonesia } \\
\hline Aku & & tiang & & $\sqrt{ }$ & kaji & saya \\
\hline Amaq & Bapaq & mamiq & & & & ayah \\
\hline Aran & & pasengan & & & & nama \\
\hline atao; atawe & & utawi & $\sqrt{ }$ & & & atau \\
\hline Anak & & bije & & & & anak \\
\hline Aoq & & nggih & $\sqrt{ }$ & $\sqrt{ }$ & meran & ya \\
\hline Ape & & napi & & $\sqrt{ }$ & & apa \\
\hline Araq & & enten & $\sqrt{ }$ & $\sqrt{ }$ & & ada \\
\hline Awak & & rage & & $\sqrt{ }$ & & badan \\
\hline Bait & & $\begin{array}{l}\text { gading; gadin- } \\
\text { gan }\end{array}$ & & & & ambil \\
\hline Badaq; baraq & & & $\sqrt{ }$ & $\sqrt{ }$ & $\begin{array}{l}\text { matur; } \\
\text { bepaice }\end{array}$ & beritahu \\
\hline Bale & & pegedengan & & & & rumah \\
\hline Bedoe & & pulih & & & & mempunyai \\
\hline Bedait & & mapak & $\sqrt{ }$ & & & bertemu; \\
\hline
\end{tabular}




\begin{tabular}{|c|c|c|c|c|c|c|}
\hline Low & Mid & High & $B J$ & $B B$ & Honorific & Indonesia \\
\hline Beli & & tumbas & $\sqrt{ }$ & $\sqrt{ }$ & & membeli \\
\hline beng; sadeq & & & $\sqrt{ }$ & & atur; ican & berikan \\
\hline dateng & & rauh & $\sqrt{ }$ & $\sqrt{ }$ & & datang \\
\hline desa/dese & & dese? & & & & desa \\
\hline endeng & & tunas & & $\sqrt{ }$ & & meminta \\
\hline gigi & & pageran & & & & gigi \\
\hline gitaq & Sereoq & sermin & & & & lihat \\
\hline ime & & gading & & & & tangan \\
\hline irup, idup & & urip & $\sqrt{ }$ & & & hidup \\
\hline kakaq & & $\begin{array}{l}\text { beli } \\
\text { mboq }\end{array}$ & & $\begin{array}{l}\sqrt{ } \\
\sqrt{ }\end{array}$ & & $\begin{array}{l}\text { kakak laki- } \\
\text { laki } \\
\text { kakak perem- } \\
\text { puan }\end{array}$ \\
\hline kamu & Side & $\begin{array}{l}\text { pelinggih atau } \\
\text { pelungguh }\end{array}$ & & & dekaji & kamu; anda \\
\hline $\begin{array}{l}\text { Kelambi; tang- } \\
\text { kong }\end{array}$ & & kuace & & & & baju \\
\hline $\begin{array}{l}\text { kembeq, kum- } \\
\text { beqna }\end{array}$ & & $\begin{array}{l}\text { napi } \\
\text { menawan/ } \\
\text { napi mawanan }\end{array}$ & $\sqrt{ }$ & $\sqrt{ }$ & & kenapa \\
\hline kepeng & & jinah & & & & uang \\
\hline lalo & & lumbar & $\sqrt{ }$ & $\sqrt{ }$ & margi & pergi \\
\hline $\begin{array}{l}\text { leq te (ite), leq } \\
\text { to (tono) }\end{array}$ & & $\begin{array}{l}\text { niki, driki; } \\
\text { nike, drike }\end{array}$ & $\sqrt{ }$ & $\sqrt{ }$ & & $\begin{array}{l}\text { ini } \\
\text { itu }\end{array}$ \\
\hline lupaq & & sisp & & & & lupa \\
\hline mama, mame & & laki & & & & laki-laki \\
\hline $\begin{array}{l}\text { mandiq; be- } \\
\text { siram }\end{array}$ & & siram & $\sqrt{ }$ & & & mandi \\
\hline mangan & Bekelor & $\begin{array}{l}\text { medahar, me- } \\
\text { daran }\end{array}$ & $\sqrt{ }$ & $\sqrt{ }$ & & makan \\
\hline mata & Penenteng & penyerminan & & & & mata \\
\hline mate & & ninggal & & & & mati \\
\hline $\begin{array}{l}\text { meno (ngeno); } \\
\text { maraq no } \\
\text { (maraq sino) }\end{array}$ & & $\begin{array}{l}\text { menike, maraq } \\
\text { nike, }\end{array}$ & $\sqrt{ }$ & $\sqrt{ }$ & & $\begin{array}{l}\text { begitu, seperti } \\
\text { itu }\end{array}$ \\
\hline $\begin{array}{l}\text { mene (ngene); } \\
\text { maraq ne } \\
\text { (maraq sine) }\end{array}$ & & $\begin{array}{l}\text { meniki; maraq } \\
\text { niki }\end{array}$ & $\sqrt{ }$ & $\sqrt{ }$ & & $\begin{array}{l}\text { begini; seperti } \\
\text { ini }\end{array}$ \\
\hline mele & & kayun & & & & mau, ingin \\
\hline mentelah & & $\begin{array}{l}\text { singgah; sim- } \\
\text { pang }\end{array}$ & & & & mampir \\
\hline milu & & & & $\sqrt{ }$ & $\begin{array}{l}\text { Ngir- } \\
\text { ing-1sg } \\
\text { (dawek)- } \\
\text { 1sg }\end{array}$ & ikut \\
\hline mpuh; mpoh & & & & & bemanik & panggil \\
\hline nae & & & & & cokor & kaki \\
\hline $\begin{array}{l}\text { nane; nani; } \\
\text { nengka }\end{array}$ & & mangkin & $\sqrt{ }$ & $\sqrt{ }$ & & sekarang \\
\hline nangis & & besermin & & & & menangis \\
\hline
\end{tabular}




\begin{tabular}{|c|c|c|c|c|c|c|}
\hline Low & Mid & High & $B J$ & $B B$ & Honorific & Indonesia \\
\hline ndeq & & nenten & $\sqrt{ }$ & $\sqrt{ }$ & & $\begin{array}{l}\text { tidak, tidak } \\
\text { ada }\end{array}$ \\
\hline $\begin{array}{l}\text { ne, ni (sine, } \\
\text { ine) }\end{array}$ & & niki & $\sqrt{ }$ & $\sqrt{ }$ & & ini \\
\hline ngeraos & & bebasa & $\sqrt{ }$ & $\sqrt{ }$ & bebaos & berbicara \\
\hline $\begin{array}{l}\text { ngerokoq; } \\
\text { merokok }\end{array}$ & & ngelanjur & & & & merokok \\
\hline nine; nina & & bini & & & & perempuan \\
\hline no; sino; ino & & nike & $\sqrt{ }$ & $\sqrt{ }$ & & itu \\
\hline nteh; teh & & silaq & & & ngiring & mari, silahkan \\
\hline oleq; uleq & & mantuk & & & & pulang \\
\hline pade; pada & & $\begin{array}{l}\text { Sami, sami } \\
\text { senamian }\end{array}$ & $\sqrt{ }$ & & & $\begin{array}{l}\text { sama, } \\
\text { semuanya }\end{array}$ \\
\hline paretoq; badaq & & Atur, aturan & $\sqrt{ }$ & $\sqrt{ }$ & & perlihatkan \\
\hline papuq mame & & Niniq laki & & & & kakek \\
\hline papuq nine & & Niniq bini & & & & nenek \\
\hline rokoq & & lanjaran & & & & rokok \\
\hline satuq & & pesjiq & & & & $\begin{array}{l}\text { menyajikan } \\
\text { (makanan) }\end{array}$ \\
\hline $\begin{array}{l}\text { sembahy ang; } \\
\text { sembayang }\end{array}$ & & munggah & $\sqrt{ }$ & & & sembahyang \\
\hline semame & & $\begin{array}{ll}\begin{array}{l}\text { Selakiq, } \\
\text { lakiqan }\end{array} & \text { se- } \\
\end{array}$ & & & & suami \\
\hline semeton & & sanaq & & & & saudara \\
\hline sengaq & & mawanan & & & & sebab \\
\hline senine & & $\begin{array}{l}\text { Sebiniq, sebi- } \\
\text { niqan }\end{array}$ & & & & isteri \\
\hline surat & & layang & & & & surat \\
\hline tabeq & & Nurge & & & & permisi \\
\hline taek & & Linggihan & $\sqrt{ }$ & & & naik \\
\hline tao & & wikan & $\sqrt{ }$ & & & tau \\
\hline tedoq & & meneng & $\sqrt{ }$ & & & diam \\
\hline temoe & & tamu & & & & tamu \\
\hline tendoq; tindoq & & mesare; mensare & $\sqrt{ }$ & $\sqrt{ }$ & & tidur \\
\hline terimaq & & & & & $\begin{array}{l}\text { tampi; pang- } \\
\text { gih }\end{array}$ & terima \\
\hline tian & & bosang & & & & perut \\
\hline toaq & & lingsir & & & lengsir & tua \\
\hline tokol & & melinggih & & & & duduk \\
\hline tukaq; kubur & & pesarean; makem & & & & \\
\hline ulu; otak & & Sirah, dohur & $\sqrt{ }$ & & & kepala \\
\hline
\end{tabular}

Keterangan Singkatan:
$\mathrm{BJ}=$ Bahasa Jawa
$\mathrm{O} 1$ = orang pertama
$\mathrm{BB}=$ Bahasa Bali
$\mathrm{O} 2$ = orang kedua
$\mathrm{O} 3=$ orang ketiga 